\title{
Size and Surface Charge Dependent Impregnation of Nanoparticles in Soft- and Hardwood ${ }^{\dagger}$
}

\author{
David Bossert ${ }^{1, \ddagger}$, Christoph Geers ${ }^{1, *, \ddagger}$, Maria Inés Placencia Peña ${ }^{2}$, Thomas Volkmer ${ }^{2}$, \\ Barbara Rothen-Rutishauser ${ }^{1}$ and Alke Petri-Fink ${ }^{1,3, *}$ \\ 1 Adolphe Merkle Institute, University of Fribourg, Chemin des Verdiers 4, 1700 Fribourg, Switzerland; \\ david.bossert@unifr.ch (D.B.); barbara.rothen@unifr.ch (B.R.-R.) \\ 2 Bern University of Applied Sciences, Architecture, Wood and Civil Engineering, Solothurnstrasse 102, \\ 2500 Biel, Switzerland; ines.placencia@gmail.com (M.I.P.P.); thomas.volkmer@bfh.ch (T.V.) \\ 3 Chemistry Department, University of Fribourg, Chemin du Musée 9, 1700 Fribourg, Switzerland \\ * Correspondence: christoph.geers@unifr.ch (C.G.); alke.fink@unifr.ch (A.P.-F.) \\ + In Honor of Professor Bernd Giese on the Occasion of His 80th Birthday. \\ $\ddagger$ These authors contributed equally.
}

Received: 2 April 2020; Accepted: 24 April 2020; Published: 2 May 2020

\begin{abstract}
Recent progress in wood preservative research has led to the use of insoluble copper carbonate in the form of nano- to micron-sized particles in combination with known triazole fungicides to combat fungal decay and thus decrease physical material properties. Evidently, particle-based agents could lead to issues regarding impregnation of a micro-structured material like wood. In this study, we analyzed these limitations via silicon dioxide particles in impregnation experiments of pine and beech wood. In our experiments, we showed that limitations already existed prior to assumed particle size thresholds of 400-600 nm. In pine wood, $70 \mathrm{~nm}$ sized particles were efficiently impregnated, in contrast to $170 \mathrm{~nm}$ particles. Further we showed that surface functionalized silica nanoparticles have a major impact on the impregnation efficiency. Silica surfaces bearing amino groups were shown to have strong interactions with the wood cell surface, whereas pentyl chains on the $\mathrm{SiO}_{2}$ surfaces tended to lower the particle-wood interaction. The acquired results illustrate an important extension of the currently limited knowledge of nanoparticles and wood impregnation and contribute to future improvements in the field of particle-based wood preservatives.
\end{abstract}

Keywords: wood; nanoparticles; surface modification; localization; distribution; impregnation; scanning electron microscopy

\section{Introduction}

Wood has unique properties and is a renewable but also degradable natural material. However, its longevity is affected by microorganisms and environmental factors, which can decompose the wood structure, leading to altered appearance and lowered stability. To counteract these, wood can be protected by a variety of methods, amongst them, for example, treatment with organic solvent preservatives, creosote or waterborne wood preservatives [1]. Among the latter, copper-containing, and in particular chromated copper arsenate (CCA), preservatives have been used in the past decades [2,3]. In 2002, approximately 30 million cubic meters of wood were treated with an estimated consumption of 500,000 tons of CCA worldwide [4]. Since 2004, arsenate-containing wood preservatives were restricted for industrial use only, and thus their demand has been declining [5]. Copper-containing formulations still prevail as the most used class of wood preserving agents due to their excellent activity against many wood-destroying organisms [6,7]. Recently, formulations using insolubilized copper species for wood preservation have been investigated [8-14]. These formulations rely on 
micronized copper (MC) particles, which are obtained from ball-milling solid copper carbonate into the size range of $1 \mathrm{~nm}-25 \mu \mathrm{m}$ particles, which are then pressure impregnated into wood [15-17]. Studies have demonstrated that micronized copper azole and micronized copper quaternary comprising wood preservatives showed better performance compared to formulations using soluble copper $[8,9,18]$. Soil $\mathrm{pH}$ and composition have drastic effects on the protective ability of MC [9,19], but overall, MC particles show much lower leaching compared to soluble copper formulations due to the reservoir effect [20]. The same effect was confirmed for other particle-based wood preservatives. For example, zinc oxide nanoparticles (NPs) showed reduced leaching compared to zinc sulfate solutions [21-23]. Other NPs used for wood protection include, for example, silver NPs, which exhibit a broad range of antimicrobial activity. In the presence of moisture, metallic silver NPs oxidize, which results in the release of silver ions. Because silver oxidation is a slow reaction, the size of the silver NPs is critical to achieve microorganism growth control. In general, the smaller the particle size, the higher the surface area, and the larger the area available for oxidation. In addition, NPs are increasingly investigated for transparent wood coatings. Such nanocomposite coatings have the potential of not only preserving the natural color of the wood, but also stabilizing the wood surface against the combined degradative effects of sunlight and moisture.

Wood preservatives are expected to impregnate via the water conducting system with membrane openings of 400-600 $\mathrm{nm}$ in diameter. These elements pose a structural limitation, and therefore larger particles are not expected to penetrate the wood structure due to the clogging of conducting pathways $[15,17]$. The latter is in line with recent findings of MC-based wood impregnation; it was shown that most of the copper particles were deposited on the wood surface since the larger particles (the bulk of the material consists of larger micron size particles [24]) could not penetrate the wood [13,24].

Particle surface charge is another important parameter to be considered. For example, positively charged NPs form stronger interactions with wood than negatively charged NPs, since cellulose fibers (i.e., cell wall constituents) are negatively charged due to presence of acidic groups (e.g., carboxyl, sulphonic acid, or hydroxyl groups). This was previously confirmed with, e.g., cationic polymers and silicon-aluminum oxide nanocomposites bearing a positive surface charge; both form strong non-covalent interactions with the anionic surface of cellulose and wood, respectively $[25,26]$. Furthermore, cationic NPs were used as nanocarriers to deliver wood preservatives into the wood structure [27,28].

Although the results of previous studies on the use of NPs for wood preservation are promising, our understanding of the new properties of the applied (nano)particles and their mode of action is still limited [29], and wood scientists have encouraged broader engagement of nanoscientists in this field [30]. In our study, we investigated the influence of particle size and surface charge during pressure impregnation of soft- and hardwood. We used spherical silicon dioxide model particles with low polydispersity to evaluate impregnation depth and efficiency as a function of particle size and surface charge.

\section{Materials and Methods}

\subsection{Synthesis of Silica Nanoparticles}

Silica NPs were synthesized following a modified Stöber method [31]. The synthesis was standardized for all particle sizes. Briefly, a solution of ethanol (absolute, Honeywell, Charlotte, NC, USA), ammonia (25\% aqueous solution, Merck, Darmstadt, Germany) and water (MilliQ, Arium 611DI, Sartorius Stedim Biotech, Göttingen, Germany) was heated to temperature (T) and equilibrated for $1 \mathrm{~h}$ before adding tetraethyl orthosilicate (TEOS, 98\%, Sigma-Aldrich, St. Louis, MO, USA). The mixture was stirred overnight at the given temperature and allowed to cool down to room temperature (RT). The formed particles were washed by three centrifugation (Heraeus Multifuge X1R, equipped with an F15-8 $\times$ 50cy fixed-angle rotor, Thermo Scientific, Waltham, MA, USA)-redispersion (MilliQ) cycles and finally dispersed in water. If the particles had to be dispersed in $\mathrm{EtOH}$, three additional 
centrifugation-redispersion $(\mathrm{EtOH})$ cycles were applied. The quantitative reaction parameters for each particle size were as follows: $\mathrm{SiO}_{2}-\mathrm{NP} 70 \mathrm{~nm}$ : water $(24.5 \mathrm{~mL}), \mathrm{EtOH}(200 \mathrm{~mL})$, ammonia $(7.8$ $\mathrm{mL})$, TEOS $(13.94 \mathrm{~mL}), \mathrm{T}=60^{\circ} \mathrm{C}$, centrifugation $(15,000 \times g, 20 \mathrm{~min}) . \mathrm{SiO}_{2}-\mathrm{NPs} 170 \mathrm{~nm}$ : MilliQ (58.5 $\mathrm{mL}), \operatorname{EtOH}(162 \mathrm{~mL})$, ammonia $(7.8 \mathrm{~mL}), \mathrm{TEOS}(22 \mathrm{~mL}), \mathrm{T}=65^{\circ} \mathrm{C}$, centrifugation $(10,000 \times \mathrm{g}, 10 \mathrm{~min})$. $\mathrm{SiO}_{2}$-NPs $350 \mathrm{~nm}$ : MilliQ (13.5 mL), EtOH (174 mL), ammonia $(40.9 \mathrm{~mL}), \mathrm{TEOS}(21 \mathrm{~mL}), \mathrm{T}=60^{\circ} \mathrm{C}$, centrifugation $(5000 \times g, 10 \mathrm{~min})$.

\subsection{Functionalization of Silica Nanoparticles}

$\mathrm{SiO}_{2}-\mathrm{NPs} 70 \mathrm{~nm}\left(100 \mathrm{~mL}\right.$ of a $7.2 \mathrm{mg} \mathrm{mL}^{-1}$ suspension in $\left.\mathrm{EtOH}, 720 \mathrm{mg} \mathrm{SiO}{ }_{2}, 12 \mathrm{mmol}\right)$, ammonia $(7.35 \mathrm{~mL}$ ) and functionalized triethoxysilane ((3-aminopropyl)triethoxysilane (APTES, $252 \mu \mathrm{L}, 321 \mu \mathrm{mol}$, Sigma-Aldrich) for APTES-SiO $270 \mathrm{~nm}$; pentyltriethoxysilane (PETES, $281 \mu \mathrm{L}, 321 \mu \mathrm{mol}$, Gelest Inc., Morrisville, PA, USA) for PETES-SiO $270 \mathrm{~nm}$ ) were mixed and stirred at reflux overnight. The reaction mixture was cooled to RT; the particles were washed by three centrifugation $(10 \mathrm{~min}, 10,000 \times g)$ and redispersion $(\mathrm{EtOH})$ cycles and finally dispersed in EtOH. To transfer the particles into water, three additional centrifugation-redispersion (water) cycles were applied. Note: The surface chemistry of amorphous silica and more specifically the hydroxylation of the silica surface was estimated by the Zhuravlev model. Equal stoichiometry was applied to ensure equivalent surface functionalization.

\subsection{Characterization of Nanoparticles}

To prepare a NP sample suitable for transmission electron microscopy (TEM), samples were prepared by diluting the particle suspension $(1 \mu \mathrm{L})$ with ethanol $(5 \mu \mathrm{L}$, absolute, Honeywell) directly on the TEM grids (carbon film, 300 mesh on Cu, Electron Microscopy Sciences, Hatfield, PA, USA) and removing the remaining liquid using a fuzz-free tissue (precision wipes, Kimtech Science, Kimberly Clark, Dallas, TX, USA). For difficult to disperse samples, the particle suspensions were treated according to a previously published protocol [32] In brief, the particle suspension was mixed with an aqueous solution of bovine serum albumin (BSA); $5 \mu \mathrm{L}$ of this mixture was drop cast onto a carbon-film square mesh copper grid (Electron Microscopy Sciences, CF-300-Cu) and dried in ambient air in a dust-free environment. The images were recorded with $2048 \times 2048$ pixels (Veleta CCD camera, Olympus, Shinjuku, Tokio, Japan) on a Tecnai Spirit transmission electron microscope (FEI), operating at an acceleration voltage of $120 \mathrm{kV}$. The size distribution of the NPs ( $>300$ particle count) was determined using particle analysis software (ImageJ, National Institutes of Health, Bethesda, MD, USA). Dynamic light scattering (DLS) data was collected at constant temperature $\left(25^{\circ} \mathrm{C}\right)$ on a commercial goniometer instrument (3D LS Spectrometer, LS Instruments AG, Fribourg, Switzerland). Zeta-potential measurements were performed using a Brookhaven Plus90 particle size analyzer (USA) measuring at a scattering angle of $90^{\circ}$ for $1 \mathrm{~min}$ and 10 repetitions. Fourier-transform infrared spectroscopy (FTIR) was measured (Spectrum 65, Perkin Elmer, Waltham, MA, USA) with lyophilized $\mathrm{SiO}_{2}$-NPs as background.

\subsection{Wood Samples}

Beech (Fagus sylvatica) and pine (Pinus sylvestris) wood were used for all experiments. The samples were selected using the EN113 [33] standard. Wood samples of $30 \times 10 \times 10 \mathrm{~mm}^{3}$ (longitudinal $\times$ radial $\times$ tangential) in size were used in all impregnation studies. The cross sections of the wood pieces were covered with solvent-free glue (picodent twinsil ${ }^{\circledR}$, Wipperfürth, Germany).

Impregnation: For impregnation, dry wood samples were placed in polypropylene flasks, the NP suspension was added, and the samples were placed in an autoclave. A vacuum of -95 mbar was applied for $20 \mathrm{~min}$ followed by a pressure cycle of 5 bars for $1 \mathrm{~h}$. These parameters are typically used in laboratory conditions for impregnation of small wood samples and can be compared to the industry scale in terms of material uptake of the wood samples. A ballasted plastic grid was used to ensure that the wood samples stayed entirely submerged in the liquid. After impregnation, the wood samples were dried in an oven at $60^{\circ} \mathrm{C}$ for $48 \mathrm{~h}$. 
Sample preparation: The wood samples were carefully split in radial or tangential directions, respectively, using a scalpel. The split in the tangential direction was positioned in the transition between early and latewood. The exposed wood surface was analyzed by scanning electron microscopy (SEM) and energy-dispersive X-ray spectroscopy (EDX) analysis.

\subsection{Scanning Electron Microscopy and EDX-Mapping}

The split wood samples were glued to graphite plates using conductive carbon paste, and the exposed wood surface was coated with a conductive layer to ensure conductivity. For SEM maps, samples were sputtered with $\mathrm{Au}$ or $\mathrm{Pd} / \mathrm{Pt}$, and the sputtered surface was connected with a silver stripe to the sample holder to ensure high conductivity for high magnifications. For low background EDX measurements, the samples were coated with carbon. The samples were analyzed on a Mira3 LM (Tescan) FE SEM scanning electron microscope (high voltage: $5 \mathrm{kV}$, working distance: $15 \mathrm{~mm}$ ) using a secondary electron (SE) detector or an Inbeam detector. The samples were mapped using an energy dispersive $\mathrm{X}$-ray spectrometer from EDAX equipped with a lithium-doped silicon detector and analyzed using EDAX Genesis software (version 5.2).

\section{Results and Discussion}

\subsection{Particle Characterization}

$\mathrm{SiO}_{2}$-NPs were synthesized as model particles to investigate the impregnation of NPs in beech and pine wood. TEM micrographs and particle size analyses are summarized in Figure 1. All particles, i.e., $\mathrm{SiO}_{2} 70 \mathrm{~nm}, \mathrm{SiO}_{2} 170 \mathrm{~nm}$ and $\mathrm{SiO}_{2} 350 \mathrm{~nm}$, showed a low polydispersity and no size overlap between the three different groups. The diameters were determined as $70.3 \pm 7.0 \mathrm{~nm}, 172.8 \pm 14.9 \mathrm{~nm}$ and $351.4 \pm 21.5 \mathrm{~nm}$, respectively. All particles were spherical and colloidally stable $(\sim-40 \mathrm{mV}$ at $\mathrm{pH} 7)$.
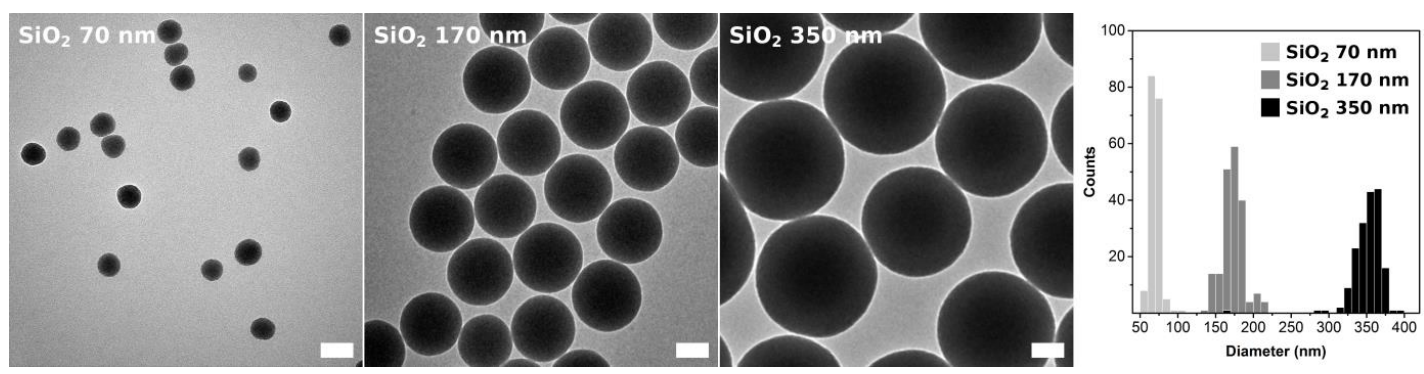

Figure 1. $\mathrm{SiO}_{2}-\mathrm{NPs}$ transmission electron micrographs and particle size distributions. The obtained mean particle diameters are $70.3 \pm 7.0 \mathrm{~nm}\left(\mathrm{SiO}_{2} 70 \mathrm{~nm}\right), 173 \pm 15 \mathrm{~nm}\left(\mathrm{SiO}_{2} 170 \mathrm{~nm}\right)$ and $351 \pm 22 \mathrm{~nm}$ $\left(\mathrm{SiO}_{2} 350 \mathrm{~nm}\right)$, respectively. Particle size distributions do not overlap (see histogram), which is important to determine impregnation size thresholds for soft- and hardwood samples. Scale bar represents $100 \mathrm{~nm}$.

$\mathrm{SiO}_{2} 70 \mathrm{~nm}$ NPs were surface-modified to investigate the interaction of wood with different particle surfaces. The results are summarized in Table 1. Successful functionalization with APTES was confirmed by a significant change of zeta-potential from $\sim-38 \mathrm{mV}\left(\mathrm{SiO}_{2}-\mathrm{NPs}\right)$ to $+42 \mathrm{mV}\left(\right.$ APTES-SiO$\left.{ }_{2}\right)$. Despite the high zeta-potential, DLS showed particle aggregation at the concentration used for wood impregnation. The same particle concentration in EtOH yielded more stable particles (Table 1), which can be explained by the stabilizing interactions between $\mathrm{EtOH}$ and the aminopropyl chain.

The pentyl group of PETES-SiO${ }_{2}$ impacted the zeta potential insignificantly compared to unfunctionalized $\mathrm{SiO}_{2}$-NPs. Additionally, the applied protocol for PETES-functionalization resulted in particles that were still dispersible in water but showed better dispersibility in EtOH. Successful functionalization was confirmed by Fourier-transform infrared spectroscopy (FTIR) of lyophilized 
particles (Supplementary Materials Figure S1), showing weak but characteristic peaks for $\mathrm{C}-\mathrm{H}$ bonds $\left(2913 \mathrm{~cm}^{-1}\right)$ and $\mathrm{Si}-\mathrm{CH}_{2}$ bonds $\left(2983 \mathrm{~cm}^{-1}, 785 \mathrm{~cm}^{-1}\right)$, in accordance with cited literature [34,35].

Table 1. Size and zeta potential of pristine and functionalized $\mathrm{SiO}_{2} 70 \mathrm{~nm}$ particles prior to impregnation.

\begin{tabular}{cccccc}
\hline \multirow{2}{*}{ Particle Type } & \multirow{2}{*}{ TEM (nm) } & \multicolumn{2}{c}{ DLS $(\mathbf{n m})$} & \multicolumn{2}{c}{ Zeta Potential (mV) } \\
\cline { 3 - 6 } & & Water & EtOH & Water & EtOH \\
\hline APTES-SiO & $68.2 \pm 10.6$ & 935.2 & 110 & 41.6 & 46.3 \\
$\mathrm{SiO}_{2}$ & $67.8 \pm 10.2$ & 88.8 & 68.8 & -37.5 & -33.1 \\
$\mathrm{PETES}-\mathrm{SiO}_{2}$ & $69.8 \pm 6.6$ & 89.8 & 99.8 & -34 & -30.1 \\
\hline
\end{tabular}

The particles were measured at $1 \mathrm{mg} \mathrm{mL}^{-1}$ as used during impregnation.

\subsection{Impregnation of Beech Wood}

Wood impregnation was analyzed by SEM-EDX mapping of wood samples (Figure 2). Figure 3 displays the SEM images and the corresponding silicon X-ray map (silicon in magenta) up to a depth of $5 \mathrm{~mm}$ (half width of sample), corresponding to full impregnation of the wood sample. The maps were recorded with the axial direction aligned vertically, from left (sample edge) to right (sample core). The particles were localized in the main components of the water conducting system, apparent from the bright colored spots in Figure 3. The strongest signal resulted from the beech vessels, indicating the water conducting system as the main entrance and distribution route. It was assumed that the large vessel diameter of around $50 \mu \mathrm{m}$ interconnected with unobstructed perforation plates allowed free movement of $\mathrm{SiO}_{2}-\mathrm{NPs}$ in suspension [36]. It was previously reported that vessel to vessel contact was not given over growth ring boundaries and, therefore, we argue that vessel-ray intersections were mainly responsible for the radial distribution of particle suspensions $[37,38]$. These results are in line with previous studies, where highly viscous tannin solutions were successfully impregnated in beech wood [39]. No signal in wood rays was detected, although wood rays are responsible for radial transport of liquid. In comparable studies [40], EDX measurements were usually acquired by preparation of flat sample surfaces (e.g., microtome cut, polished surfaces), and high topography samples suffered from absorption of emitted X-rays before reaching the detector.

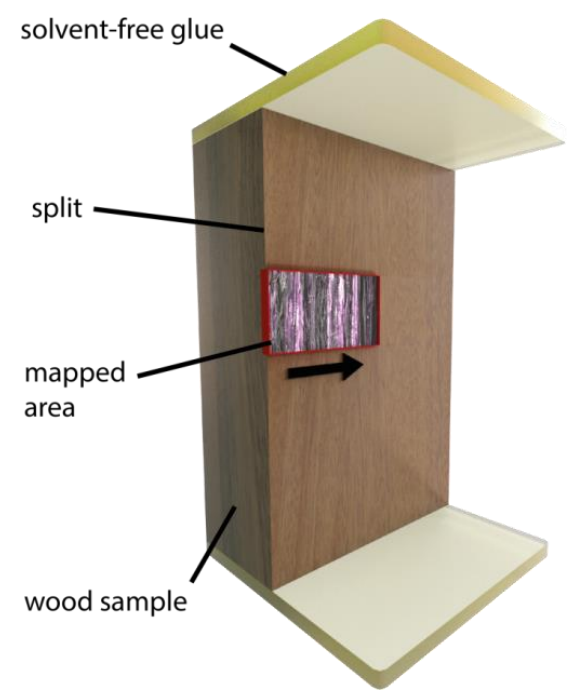

Figure 2. Illustration of wood sample preparation for SEM-EDX mapping. The cross sections were closed with a solvent-free glue to force radial and tangential particle penetration. The arrow represents the direction of impregnation from sample edge towards the core. 

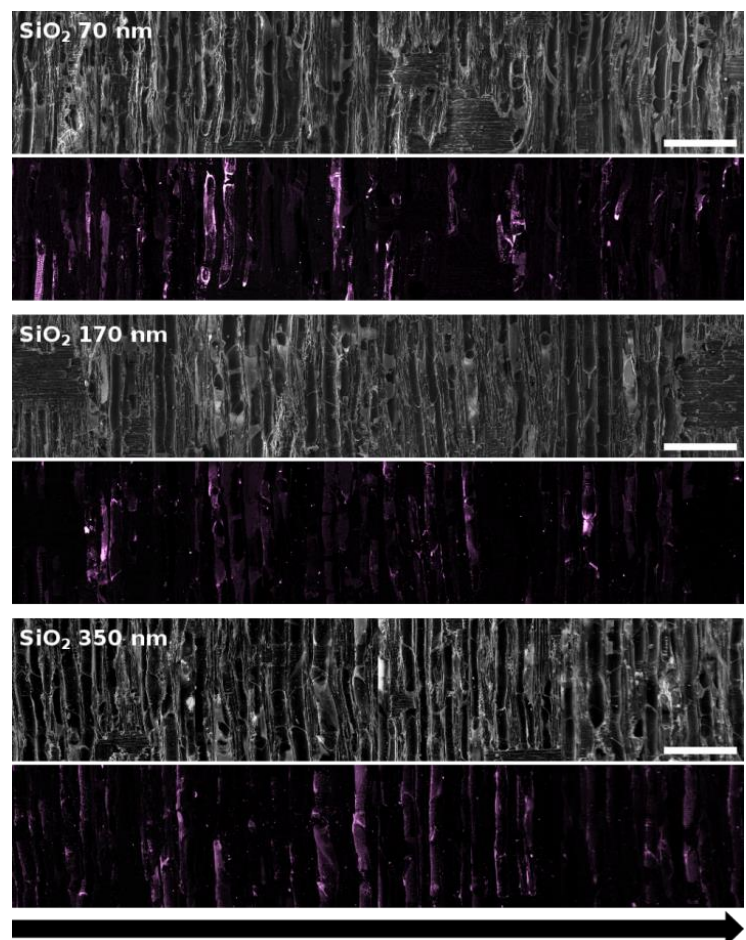

Figure 3. SEM-EDX analysis on split beech wood samples. The EDX map, with the silicon signal pseudo-colored in pink, is shown below each SEM map. Particles were detected mostly in large structures, e.g., vessel elements. All three investigated $\mathrm{SiO}_{2}$ particle sizes penetrated beech wood samples down to the maximal depth of $5 \mathrm{~mm}$. The arrow indicates the direction of impregnation, and the scale bar represents $500 \mu \mathrm{m}$.

Additionally, we tested the impregnation of $\mathrm{SiO}_{2} 70 \mathrm{~nm}$ suspensions in $\mathrm{EtOH}$. As depicted in Figure $4, \mathrm{SiO}_{2}-\mathrm{NPs}$ were distributed uniformly on the vessel walls. The particles were colloidally stable in both water and $\mathrm{EtOH}$ prior to impregnation. Faster evaporation of $\mathrm{EtOH}$ compared to water could have contributed substantially to the observed effect when drying the wood samples at $60^{\circ} \mathrm{C}$.

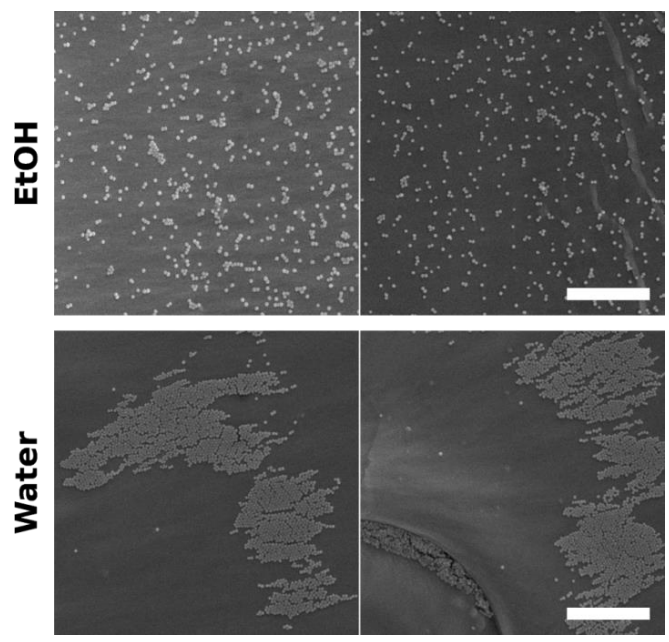

Figure 4. $\mathrm{SiO}_{2} 70 \mathrm{~nm}$ were transferred to either water or ethanol and impregnated into beech wood samples. The particles are detected primarily in the vessel elements, and particles suspended in ethanol were well dispersed over the vessel surface, whereas particles suspended in water aggregated locally. Neither suspensions were aggregated prior to impregnation (Table 1). The scale bar represents $2 \mu \mathrm{m}$. 
Overall the results showed complete penetration of all particle sizes, and no evident threshold could be detected for beech wood in the size range investigated. Although the connecting pit structures are the dimensionally most restricting structural elements of hardwood, their diameter of 4-10 $\mu \mathrm{m}$ [36] (which depends on the type of pit and hardwood species) clearly is above the requirements for physical penetration of the here investigated particle sizes.

\subsection{Impregnation of Pine Wood}

$\mathrm{SiO}_{2}$-NPs were impregnated in pine wood samples with closed cross-section and split in the radial direction (Figure 2). Figure 5 displays the SEM images and the corresponding silicon X-ray map (silicon signal in magenta). The samples were measured again down to $5 \mathrm{~mm}$, which corresponds to the half width of the wood sample. For $\mathrm{SiO}_{2} 70 \mathrm{~nm}$, a signal was observed over the whole range, and particles were detected mainly in the water conducting system of softwood, i.e., in the tracheids. We observed particle accumulation in the ray cells and in areas of bordered pits, visible by the bright spots in the EDX-map of $\mathrm{SiO}_{2} 70 \mathrm{~nm}$. This indicated that the particles entered via ray parenchyma and subsequently distributed via half-bordered pits into tracheids.
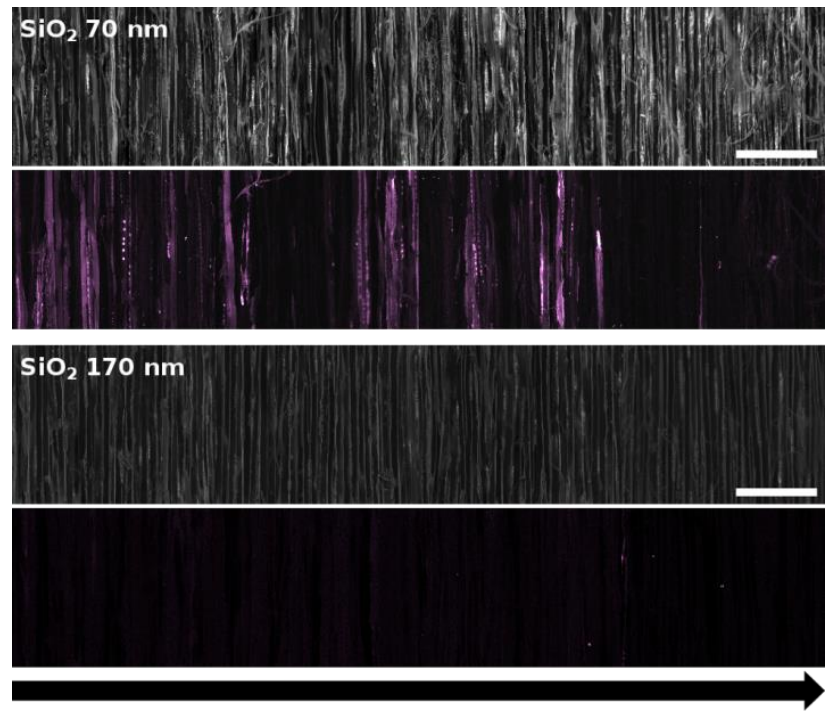

Figure 5. SEM-EDX analysis on split pine wood samples impregnated with the same particles used for beech wood. The corresponding EDX map below each SEM map shows thorough impregnation of $\mathrm{SiO}_{2} 70 \mathrm{~nm}$, but only background noise in the case of pine samples impregnated with $\mathrm{SiO}_{2} 170 \mathrm{~nm}$. The arrow indicates the direction of impregnation and the scale bar represents $500 \mu \mathrm{m}$.

EDX maps of pine samples impregnated with $\mathrm{SiO}_{2} 170 \mathrm{~nm}$ (Figure 5, $\mathrm{SiO}_{2} 170 \mathrm{~nm}$ ) showed only marginal impregnation with NPs. Similar to beech wood, the connecting features were the bottleneck for impregnation since the diameter of tracheids is much larger $(20-40 \mu \mathrm{m})$ than the diameter of the applied $\mathrm{SiO}_{2}$ NPs [41,42]. The bordered pits and half-bordered pits, which are responsible for the intertracheid and the tracheid to ray parenchyma transport of liquids, respectively, are permeable for particles with a diameter of 400-600 nm with their pit membrane intact $[17,43]$. The pit membranes were not aspirated as this would completely seal off any liquid transport between the lumen and would therefore hinder the impregnation drastically. Comparison to previously published studies is difficult, since either particles with different particle sizes $[27,44,45]$ or very broad particle size distributions $[14,46,47]$ are reported, which makes it impossible to unambiguously define particle size thresholds. In our study, we observed a much lower size limit for particle impregnation in pine wood impregnation than the reported 400-600 nm. Arguably, the fraction of smaller particles mostly contributed to impregnation in the reported studies, and the larger particles were just deposited on the surface of the wood sample. 


\subsection{Influence of the Particle Surface on Impregnation}

In the next step, we investigated the influence of surface properties on impregnation (efficiency) of $\mathrm{SiO}_{2} 70 \mathrm{~nm}$. The impregnated samples were analyzed by SEM and the results are presented in Figures 6-8. Pristine $\mathrm{SiO}_{2} 70 \mathrm{~nm}$ and PETES-SiO $\mathrm{S}_{2} 70 \mathrm{~nm}$ showed stronger impregnation compared to APTES-SiO 2 . Pristine $\mathrm{SiO}_{2} 70 \mathrm{~nm}$ particles were detected in pine wood down to $5 \mathrm{~mm}$ (Figure 6), confirming the results of a previous study [27]. In some spots (Figure 6, pictures 4, 6, 8 and 10), the particles were aggregated on the cell wall. This could be explained by interferences of $\mathrm{SiO}_{2}$ with possible extractives during the impregnation process. Extractives have shielding effects, which lower the charge and thus the electrostatic repulsion between the particles. Samples impregnated with APTES-SiO $270 \mathrm{~nm}$ did not penetrate the sample, as shown by SEM (Figure 7). Although the TEM size of APTES-SiO ${ }_{2}$ was comparable to the pristine particles (Table 1), DLS showed that the particles flocculated at the concentrations used for impregnation, i.e., above the determined threshold of 400-600 $\mathrm{nm}$. APTES-SiO${ }_{2}$ were more stable in EtOH than in water (Table 1). However, impregnation of pine samples with APTES-SiO 2 in EtOH only marginally improved wood infiltration (Supplementary Materials Figure S2), indicating that particle size (alone) is not the determining parameter, as shown previously by Renneckar et al. [25]. APTES-SiO 2 NPs can interact with the wood surface through the aminopropyl functional groups, since amine groups act as hydrogen-bond donors and acceptors, thus facilitating the interactions with the cellulose surface of the cell wall.

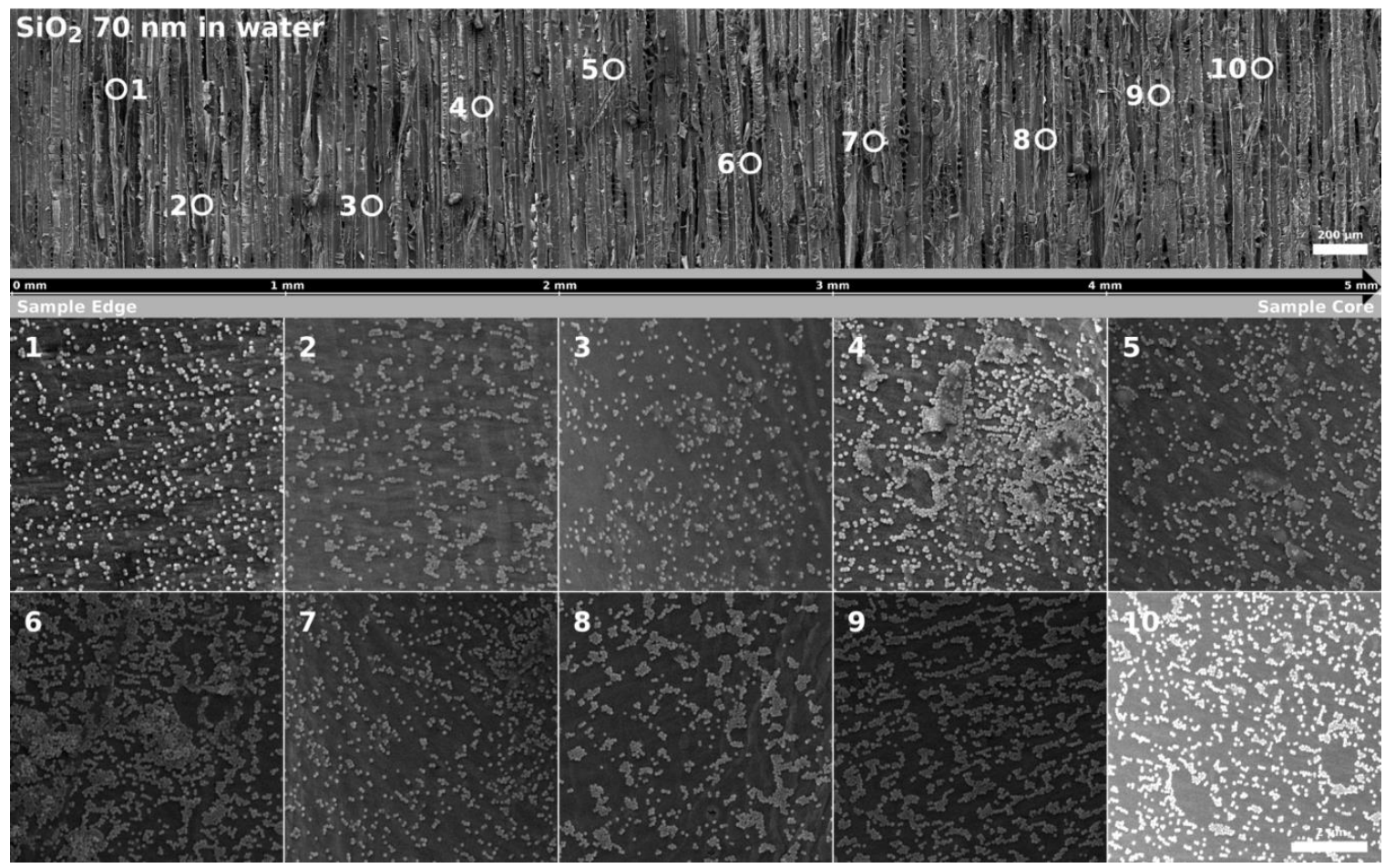

Figure 6. SEM analysis on split pine wood samples impregnated with pristine $\mathrm{SiO}_{2} 70 \mathrm{~nm}$ particles. Particles were detected until the maximum invested depth of $5 \mathrm{~mm}$ and were located in the water conducting system and on the cell wall. Some degree of aggregation was observed after drying, although the NPs were stable prior to and after the impregnation. 


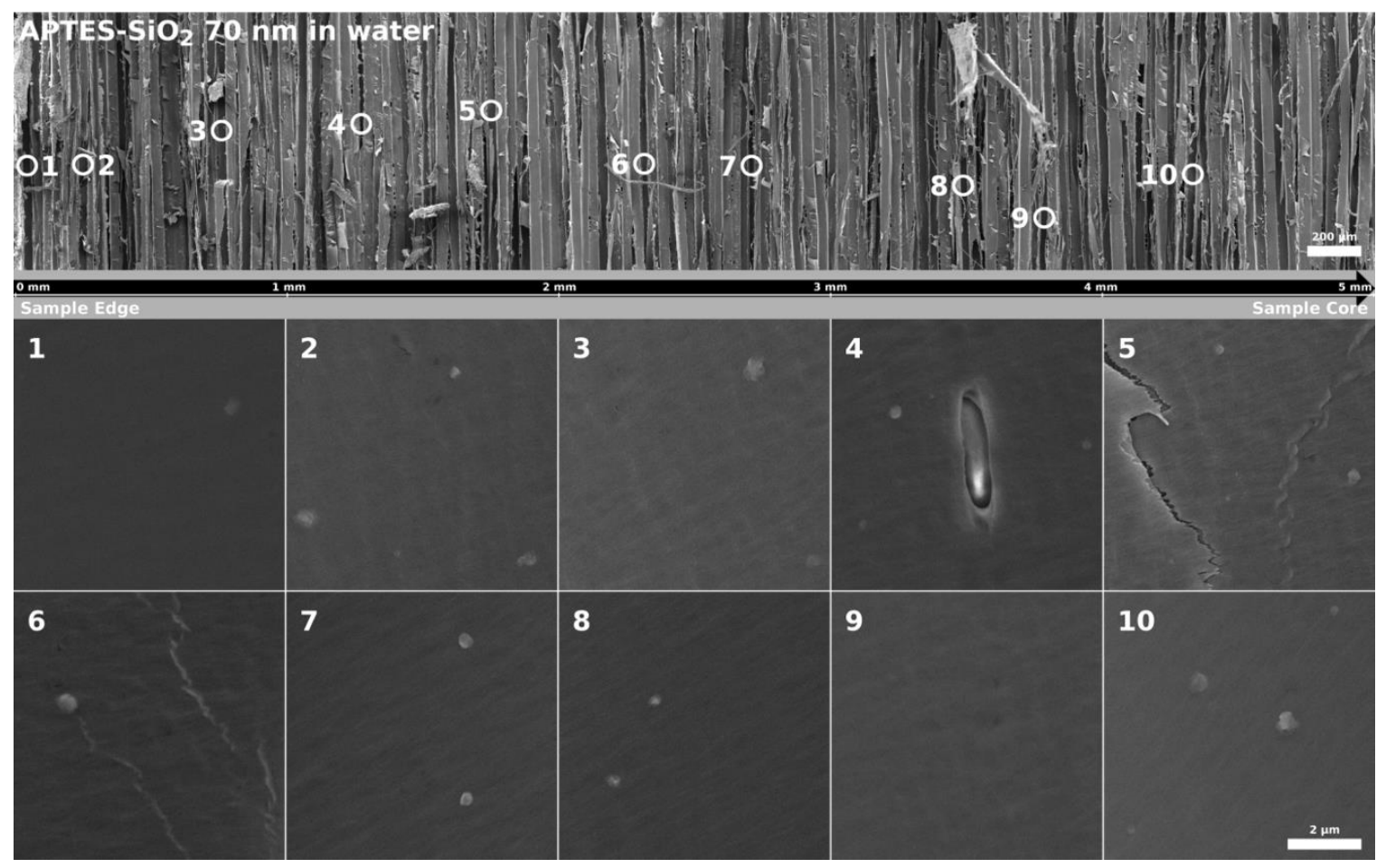

Figure 7. SEM analysis of split wood samples pressure-treated with APTES- $\mathrm{SiO}_{2} 70 \mathrm{~nm}$ does not show any impregnation. No particles can be detected even in the tracheids closest to the sample edge. Suspensions of APTES- $\mathrm{SiO}_{2} 70 \mathrm{~nm}$ in water were not sufficiently stable during the impregnation and large aggregates were probably filtered by the wood structure.
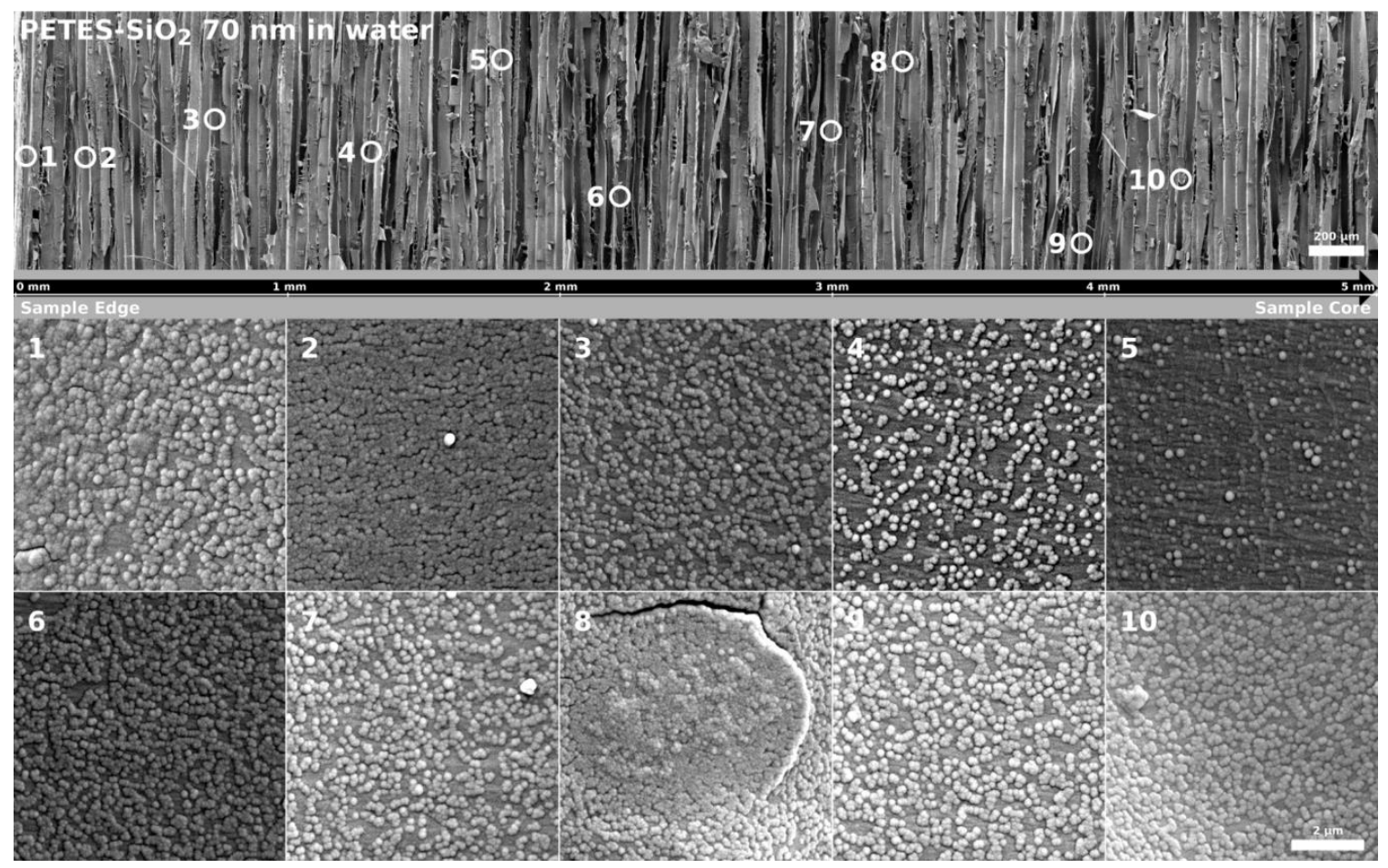

Figure 8. SEM analysis of wood samples impregnated with $\mathrm{PETES}-\mathrm{SiO}_{2} 70 \mathrm{~nm}$. Particles are easily detectable and form almost confluent sheets. Functionalization with pentyl groups allows for deeper penetration of high amounts of particles. 
As shown in Figure 8, the impregnation of PETES-SiO ${ }_{2}$ was similar to what we observed with pristine $\mathrm{SiO}_{2}$-NPs. PETES-SiO 2 were detected down to $5 \mathrm{~mm}$ in the lumens of tracheids. However, in comparison to pristine $\mathrm{SiO}_{2}$-NPs, PETES-SiO 2 were found in almost confluent sheets even at the maximal depth, indicating that the introduction of pentyl groups on the $\mathrm{SiO}_{2}$ surface could partially shield any interaction between pristine $\mathrm{SiO}_{2}$ and the cellulose cell wall surface. This may explain the deeper penetration and almost full coverage of tracheids with $\mathrm{PETES}-\mathrm{SiO}_{2}$ (Figure 6). The ability of PETES-SiO ${ }_{2}$ to form a confluent layer of particles could be applied to further investigations on similar particles with sufficient hydrophobicity [48] to introduce a hydrophobic character to wood, which hinders water uptake and hence such adverse effects as fungal decay or dimensional instability $[49,50]$ However, $\mathrm{SiO}_{2}$-NPs with a much more hydrophobic surface would not be stable in aqueous suspension [51], which is why we also dispersed and impregnated PETES-SiO ${ }_{2}$ in EtOH (Supplementary Materials Figure S3). Although $\mathrm{SiO}_{2}-\mathrm{NPs}$ and $\mathrm{PETES}-\mathrm{SiO}_{2}$ were found in the wood

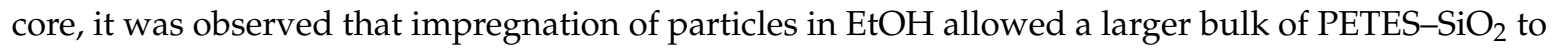
penetrate to the core of the samples. No aggregation in pine wood was observed for formulations, similar to the described phenomena in beech vessels.

\section{Conclusions}

Pine and beech wood samples with closed cross sections were pressure-treated with $\mathrm{SiO}_{2}-\mathrm{NPs}_{\mathrm{s}}$ the size range from 70 to $350 \mathrm{~nm}$. Particles were detected on the cell walls in the water conducting elements in beech and pine wood. For beech wood, all sizes were successfully impregnated, but for pine wood, the size threshold was found to be lower than previously reported [17]; $70 \mathrm{~nm}$ NPs were successfully incorporated, whereas $170 \mathrm{~nm}$ NPs were no longer impregnated in pine wood. These results are in line with common findings of high loads of superficial particulate preserving agents filtered by the wood structure. Particle-bearing formulations with defined size distributions below the physical size restrictions of a particular wood species are expected to have improved structural penetration and hence better resistance towards leaching.

The impact of surface functionalization was investigated on $\mathrm{SiO}_{2} 70 \mathrm{~nm}$. Our investigations showed that colloidal stability (i.e., aggregation behavior) and surface charge have a significant impact on particle impregnation. Compared to unfunctionalized $\mathrm{SiO}_{2}$ particles, PETES-functionalization enhanced particle infiltration. APTES-SiO ${ }_{2}$ particles, featuring amine groups on the surface, were not impregnated, neither in water nor in ethanol. In water, particles were colloidally instable and the resulting aggregates were "filtered" by the wood structure. The same particles were colloidally more stable in ethanol, but showed only minor improvement with respect to penetration depth, probably due to strong interactions of the positive amine groups with the (negatively charged) cellulose/hemicellulose cell wall surface.

Supplementary Materials: The following are available online at http://www.mdpi.com/2624-8549/2/2/23/s1, Figure S1: Pine wood impregnation of pristine $\mathrm{SiO}_{2} 70 \mathrm{~nm}$ nanoparticles dispersed in $\mathrm{EtOH}$, Figure S2: Impregnation of APTES-SiO $270 \mathrm{~nm}$ in EtOH, Figure S3: Impregnation of PETES-SiO $270 \mathrm{~nm}$ in EtOH.

Author Contributions: D.B. and C.G. contributed equally to this work and have prepared and characterized all particles, recorded all SEM images and performed wood impregnation together with M.I.P.P. and T.V. The manuscript was written by D.B., C.G. and A.P.-F. with input from B.R.-R. and T.V. All authors have read and agreed to the published version of the manuscript.

Funding: This work was financially supported by the Swiss National Foundation (136976), the Adolphe Merkle Foundation and the University of Fribourg.

Acknowledgments: We would like to thank Miguel Spuch for preparing Figure 2.

Conflicts of Interest: The authors declare no conflict of interest. 


\section{References}

1. European Industry Trade Association Representing the Pressure Treated Wood Industry. Available online: http://www.wei-ieo.org/woodpreservation.html (accessed on 17 March 2018).

2. Mohajerani, A.; Vajna, J.; Ellcock, R. Chromated copper arsenate timber: A review of products, leachate studies and recycling. J. Clean. Prod. 2018, 179, 292-307. [CrossRef]

3. Borazjani, H.; Ferguson, B.J.; McFarland, L.K.; McGinnis, G.D.; Pope, D.F.; Strobel, D.A.; Wagner, J.L. Evaluation of Wood-Treating Plant Sites for Land Treatment of Creosote- and Pentachlorophenol-Contaminated Soils. ACS Sym. Ser. 1990, 422, 252-266.

4. Humphrey, D.G. The chemistry of chromated copper arsenate wood preservatives. Rev. Inorg. Chem. 2002, 22, 1-40. [CrossRef]

5. Regulation (EC) No 1907/2006 of the European Parliament and of the Council. Available online: https: //eur-lex.europa.eu/legal-content/EN/TXT/?uri=CELEX\%3A02006R1907-20140410 (accessed on 14 March 2018).

6. Humar, M.; Lesar, B. Fungicidal properties of individual components of copper-ethanolamine-based wood preservatives. Int. Biodeterior. Biodegrad. 2008, 62, 46-50. [CrossRef]

7. Gadd, G.M. Interactions of fungip with toxic metals. New Phytol. 1993, 124, 25-60. [CrossRef]

8. Nicholas, D. Performance of waterborne copper/organic wood preservatives in an AWPA E14 soft-rot laboratory soil bed test using modified soil. Holzforschung 2017, 71, 759-763. [CrossRef]

9. Xue, W.; Ruddick, J.N.R.; Kennepohl, P. Solubilisation and chemical fixation of copper(ii) in micronized copper treated wood. Dalton Trans. 2016, 45, 3679-3686. [CrossRef]

10. Xue, W.; Kennepohl, P.; Ruddick, J.N. Reacted copper(II) concentrations in earlywood and latewood of micronized copper-treated Canadian softwood species. Holzforschung 2015, 69, 509-512. [CrossRef]

11. Schmitt, S.; Zhang, J.; Shields, S.; Schultz, T.P. Copper-Based Wood Preservative Systems Used for Residential Applications in North America and Europe. ACS Symp. Ser. 2014, 1158, 217-225.

12. Platten, W.E.; Luxton, P.T.; Gerke, T.; Harmon, S.; Sylvest, N.; Bradham, K.; Rogers, K. Release of Micronized Copper Particles from Pressure-Treated Wood Products; EPA Report; United States Environmental Protection Agency: Washington, DC, USA, 2014. Available online: https://cfpub.epa.gov/si/si_public_record_report. cfm?dirEntryId=307040\&Lab=NRMRL (accessed on 14 March 2018).

13. Civardi, C.; Bulcke, J.V.D.; Schubert, M.; Michel, E.; Butron, M.I.; Boone, M.; Dierick, M.; Van Acker, J.; Wick, P.; Schwarze, F.W.M. Penetration and Effectiveness of Micronized Copper in Refractory Wood Species. PLOS ONE 2016, 11, e0163124. [CrossRef]

14. Civardi, C.; Schubert, M.; Fey, A.; Wick, P.; Schwarze, F.W.M. Micronized Copper Wood Preservatives: Efficacy of Ion, Nano, and Bulk Copper against the Brown Rot Fungus Rhodonia placenta. PLoS ONE 2015, 10, e0142578. [CrossRef] [PubMed]

15. Zhang, J.; Zhang, W. Micronized Wood Preservative Formulations Comprising Copper and Zinc; Osmose, Inc.: Atlanta, GA, USA, 2009.

16. Leach, R.M.; Zhang, J. Micronized Wood Preservative Compositions. U.S. Patent Application 20060288904, 28 December 2006.

17. Freeman, M.H.; McIntyre, C.R. A Comprehensive Review of Copper-Based Wood Preservatives. For. Prod. J. 2008, 58, 6-27.

18. McCallan, S.E.A. The nature of the fungicidal action of copper and sulfur. Bot. Rev. 1949, 15, 629-643. [CrossRef]

19. Pankras, S.; Cooper, P.A. Effect of ammonia addition to alkaline copper quaternary wood preservative solution on the distribution of copper complexes and leaching. Holzforschung 2012, 66. [CrossRef]

20. Freeman, M.H.; McIntyre, C.R. Micronized Copper Wood Preservatives: Strong indications of the Reservoir Effect. In Proceedings of the IRG Annual Meeting, Stockholm, Sweden, 16-20 June 2013.

21. Clausen, C.A.; Kartal, S.N.; Arango, R.A.; Green, F. Erratum to: The role of particle size of particulate nano-zinc oxide wood preservatives on termite mortality and leach resistance. Nanoscale Res. Lett. 2011, 6, 465. [CrossRef]

22. Kartal, S.N.; Green, F.; Clausen, C. Do the unique properties of nanometals affect leachability or efficacy against fungi and termites? Int. Biodeterior. Biodegradation 2009, 63, 490-495. [CrossRef] 
23. Ghorbani, M.; Taghiyari, H.R.; Siahposht, H. Effects of heat treatment and impregnation with zinc-oxide nanoparticles on physical, mechanical, and biological properties of beech wood. Wood Sci. Technol. 2014, 48, 727-736. [CrossRef]

24. Clar, J.; Platten, W.E.; Baumann, E.J.; Remsen, A.; Harmon, S.M.; Bennett-Stamper, C.L.; Thomas, T.A.; Luxton, T.P. Dermal transfer and environmental release of $\mathrm{CeO}_{2}$ nanoparticles used as UV inhibitors on outdoor surfaces: Implications for human and environmental health. Sci. Total. Environ. 2018, 613, 714-723. [CrossRef]

25. Renneckar, S.; Zhou, Y. Nanoscale Coatings on Wood: Polyelectrolyte Adsorption and Layer-by-Layer Assembled Film Formation. ACS Appl. Mater. Interfaces 2009, 1, 559-566. [CrossRef]

26. Nechyporchuk, O.; Bordes, R.; Köhnke, T. Wet Spinning of Flame-Retardant Cellulosic Fibers Supported by Interfacial Complexation of Cellulose Nanofibrils with Silica Nanoparticles. ACS Appl. Mater. Interfaces 2017, 9, 39069-39077. [CrossRef]

27. Geers, C.; Rodriguez-Lorenzo, L.; Peña, M.I.P.; Brodard, P.; Volkmer, T.; Rothen-Rutishauser, B.; Petri-Fink, A. Distribution of Silica-Coated Silver/Gold Nanostars in Soft- and Hardwood Applying SERS-Based Imaging. Langmuir 2015, 32, 274-283. [CrossRef] [PubMed]

28. Liu, Y.; Laks, P.; Heiden, P. Nanoparticles for the Controlled Release of Fungicides in Wood: Soil Jar Studies Using G. Trabeum and T. Versicolor Wood Decay Fungi. Holzforschung 2003, 57, 135-139. [CrossRef]

29. Evans, P.; Matsunaga, H.; Kiguchi, M. Large-scale application of nanotechnology for wood protection. Nat. Nanotechnol. 2008, 3, 577. [CrossRef]

30. Beecher, J.F. Wood, trees and nanotechnology. Nat. Nanotechnol. 2007, 2, 466-467. [CrossRef] [PubMed]

31. Stöber, W.; Fink, A.; Bohn, E. Controlled growth of monodisperse silica spheres in the micron size range. J. Colloid Interface Sci. 1968, 26, 62-69. [CrossRef]

32. Michen, B.; Geers, C.; Vanhecke, D.; Endes, C.; Rothen-Rutishauser, B.; Balog, S.; Petri-Fink, A. Avoiding drying-artifacts in transmission electron microscopy: Characterizing the size and colloidal state of nanoparticles. Sci. Rep. 2015, 5, 9793. [CrossRef]

33. British Standards Institution. Wood Preservatives. Test Method for Determining the Protective Effectiveness against Wood Destroying Basidiomycetes. Determination of the Toxic Values. 1997. Available online: https://shop.bsigroup.com/ProductDetail?pid=000000000030112176 (accessed on 14 March 2018).

34. Rahman, I.; Jafarzadeh, M.; Sipaut, C.S. Synthesis of organo-functionalized nanosilica via a co-condensation modification using $\gamma$-aminopropyltriethoxysilane (APTES). Ceram. Int. 2009, 35, 1883-1888. [CrossRef]

35. Sriramulu, D.; Reed, E.L.; Annamalai, M.; Venkatesan, T.V.; Valiyaveettil, S. Synthesis and Characterization of Superhydrophobic, Self-cleaning NIR-reflective Silica Nanoparticles. Sci. Rep. 2016, 6, 35993. [CrossRef]

36. Wagenführ, R. Anatomie des Holzes: Struktur, Identifizierung, Nomenklatur, Mikrotechnologie, 5th ed.; DRW Verlag: Leinfelden-Echterdingen, Germany, 1999.

37. Hass, P.; Wittel, F.K.; McDonald, S.A.; Marone, F.; Stampanoni, M.; Herrmann, H.J.; Niemz, P. Pore space analysis of beech wood: The vessel network. Holzforschung 2010, 64, 639-644. [CrossRef]

38. Kucera, L. Die dreidimensionale Strukturanalyse des Holzes. Holz Roh Werkst. 1975, 33, 276-282. [CrossRef]

39. Tondi, G.; Thevenon, M.F.; Mies, B.; Standfest, G.; Petutschnigg, A.; Wieland, S. Impregnation of Scots pine and beech with tannin solutions: Effect of viscosity and wood anatomy in wood infiltration. Wood Sci. Technol. 2013, 47, 615-626. [CrossRef] [PubMed]

40. Matsunaga, H.; Kiguchi, M.; Roth, B.; Evans, P. Visualisation of Metals in Pine Treated with Preservative Containing Copper and Iron Nanoparticles. IAWA J. 2008, 29, 387-396. [CrossRef]

41. Mencuccini, M.; Grace, J.; Fioravanti, M. Biomechanical and hydraulic determinants of tree structure in Scots pine: Anatomical characteristics. Tree Physiol. 1997, 17, 105-113. [CrossRef] [PubMed]

42. Kilpeläinen, A.; Gerendiain, A.Z.; Luostarinen, K.; Peltola, H.; Kellomäki, S. Elevated temperature and CO(2) concentration effects on xylem anatomy of Scots pine. Tree Physiol. 2007, 27, 1329-1338. [CrossRef]

43. Clausen, C.A.; Green, F.; Kartal, S.N. Weatherability and Leach Resistance of Wood Impregnated with Nano-Zinc Oxide. Nanoscale Res. Lett. 2010, 5, 1464-1467. [CrossRef]

44. Dong, Y.; Yan, Y.; Zhang, S.; Li, J.; Wang, J. Flammability and physical-mechanical properties assessment of wood treated with furfuryl alcohol and nano-SiO 2 . Holz Roh Werkst. 2015, 73, 457-464. [CrossRef]

45. Soltani, M.; Najafi, A.; Yousefian, S.; Naji, H.; Bakar, E.S. Water Repellent Effect and Dimension Stability of Beech Wood Impregnated with Nano-Zinc Oxide. Bioresources 2013, 8, 6280-6287. [CrossRef] 
46. Alex, T. Short Communication: The clay nanoparticle impregnation for increasing the strength and quality of sengon (Paraserianthes falcataria) and white meranti (Shorea bracteolata) timber. Nusant. Biosci. 2017, 9, 107-110. [CrossRef]

47. Matsunaga, H.; Kiguchi, M.; Evans, P.D. Microdistribution of copper-carbonate and iron oxide nanoparticles in treated wood. J. Nanoparticle Res. 2008, 11, 1087-1098. [CrossRef]

48. Mahltig, B.; Bottcher, H. Modified Silica Sol Coatings for Water-Repellent Textiles. J. Sol.-Gel Sci. Technol. 2003, 27, 43-52. [CrossRef]

49. Lourençon, T.V.; Mattos, B.; Cademartori, P.H.; Magalhães, W.L.E. Bio-oil from a fast pyrolysis pilot plant as antifungal and hydrophobic agent for wood preservation. J. Anal. Appl. Pyrolysis 2016, 122, 1-6. [CrossRef]

50. Wang, X.; Chai, Y.; Liu, J. Formation of highly hydrophobic wood surfaces using silica nanoparticles modified with long-chain alkylsilane. Holzforschung 2013, 67, 667-672. [CrossRef]

51. Pellegrino, T.; Manna, L.; Kudera, S.; Liedl, T.; Koktysh, D.; Rogach, A.L.; Keller, S.; Rädler, J.; Natile, G.; Parak, W.J. Hydrophobic Nanocrystals Coated with an Amphiphilic Polymer Shell: A General Route to Water Soluble Nanocrystals. Nano Lett. 2004, 4, 703-707. [CrossRef]

(C) 2020 by the authors. Licensee MDPI, Basel, Switzerland. This article is an open access article distributed under the terms and conditions of the Creative Commons Attribution (CC BY) license (http://creativecommons.org/licenses/by/4.0/). 